\title{
Will the epidemic of diabetes in India subside?
}

\author{
Hemraj B. Chandalia
}

Published online: 15 May 2011

(C) Research Society for Study of Diabetes in India 2011

The epidemiologists have been prolific in disseminating the data on the cross-sectional and follow-up studies on the high prevalence of diabetes in India and predicting its alarming trends [1-4]. This journal has carried several articles [5-10] further bringing out the data on the differences between urban and rural prevalence of diabetes. This issue of the journal contains an article showing the difference in the cardiovascular risk factors in the rural versus urban population [11]. This has served a useful purpose of bringing in focus the double-burden of transiting communicable diseases and newly entering noncommunicable diseases. This has helped the government and Indian council of Medical Research to further strategize regarding the prevention of diabetes.

The rising trends of type 2 diabetes, both in the developed and developing world have been predicted mostly by using $2-3$ points of observation $5-10$ years apart in many countries [12] including in India [13, 14]. These observations are valid for the current period and probably for the near future. However, it will not be scientific to accept them as accurate predictions beyond the coming decade.

There are several important reasons why these predictions will be proven to be inaccurate. First of all, we are considering a biological phenomenon, with its inherent variability, which will influence the course of the predictive straight line. It is obviously a dynamic situation and we really do not know where the next point will come to lie. As a matter of fact if you continue to extrapolate the present

H. B. Chandalia $(\square)$

103-104 Lady Ratan Tata Medical Centre,

M. Karve Road,

Mumbai 400 021, India

e-mail: ijddcjournal@gmail.com straight line, you will reach a figure of $100 \%$ of Indians being diabetic in the distant future. This argument, although facetious, brings out the absurdities of such long term projections. As a matter of fact, CURES [14] has already shown some degree of leveling of the line, evidenced by the fact that the prevalence of diabetes in Chennai showed a rise of $39.8 \%$ between $1989-1995,16.3 \%$ between 1995 2000 and 6\% between the year 2000-2004. Numerous dynamic factors that we know and understand and which we do not know can influence the prevalence of diabetes, although hard evidence and quantitation of their impact has not been assessed. (Table 1). So far, not many epidemiologists have seriously looked at these possibilities, except for a brief reference to these factors and showing short term effect of modifying these factors individually and thus producing a favourable environment or behavioural changes. However, whether this will translate into reduced incidence of diabetes has not been studied. Many of the factors in Table 1 likely to influence the prevalence of type 2 diabetes are interdependent, like obesity is dependent on income, education and urbanization. Additionally, there may be many other factors like the quality of air, water, food, and exposure to chemicals influencing the prevalence of diabetes. The demographic structure of the Indian population as reported in the year 2001 [15] showed that 0-19 year age accounted for $45.6 \%$ while $50-80$ year or above accounted for $13.4 \%$ of the population. The current grim scenario exists inspite of the fact that the Indian population predominantly consists of young people. After 3-4 decades, when again older people account for a large proportion of population, a second wave of diabetes is possible. High prevalence of obesity in adolescents as reported from India [16] will aggravate the situation. These data will be further modified by the changing birth and death rates. 
Table 1 Factors likely to influence prevalence of type 2 diabetes

\begin{tabular}{|c|c|c|c|}
\hline & Factors & Factor likely to increase prevalence & Factor likely to decrease prevalence \\
\hline 1 & $\begin{array}{l}\text { Demography of the } \\
\text { population }\end{array}$ & Increasing life span & Increase in younger age groups \\
\hline 2 & Obesity & Increasing obesity & Decreasing obesity \\
\hline 3 & Education & Continuing lower educational status & Rapidly increasing general and health education \\
\hline 4 & Income & $\begin{array}{l}\text { Increasing income (specially when accompanied } \\
\text { by poor educational inputs) }\end{array}$ & $\begin{array}{l}\text { Increasing income (specially when accompanied by } \\
\text { enhanced educational inputs) }\end{array}$ \\
\hline 5 & Genetic factors & $\begin{array}{l}\text { Increased prevalence till adverse environment } \\
\text { has acted on most genetically susceptible } \\
\text { population }\end{array}$ & Stabilizing influence of genetically non-susceptible group \\
\hline 6 & Physical activity & $\begin{array}{l}\text { Decreased activity due to urbanization and } \\
\text { poor built environment }\end{array}$ & $\begin{array}{l}\text { Increased physical activity by introducing healthy } \\
\text { lifestyle through education and better town planning }\end{array}$ \\
\hline 7 & Diet & $\begin{array}{l}\text { Increased calories, saturated fat, sugar and } \\
\text { refined food intake }\end{array}$ & $\begin{array}{l}\text { Decreased calories, saturated fat, sugar and refined } \\
\text { food intake }\end{array}$ \\
\hline 8 & Mental stress & High stress with poor quality of life & Peaceful and good quality of life \\
\hline
\end{tabular}

Influence of enhanced income on the prevalence of obesity and diabetes can be in either direction; when coupled with education the prevalence decreases but increasing income alone increases obesity and presumably diabetes. Women of higher socio-economic status tend to be overweight [17]. However, education has a dampening effect on the cardiovascular risk factors like hypercholesterolemia, hypertension, obesity and smoking [18].

Urbanisation has a profound effect on the prevalence of diabetes. However, how urbanization leads to the escalation of obesity, is uncertain. It may be due to decreased physical activity and increased intake of saturated fat and calories [19].

Indian epidemiologists, diabetologists and healthcare personnel have not yet articulated the influence of poor built environment on the prevalence of diabetes, except for an occasional article [20]. Elaborating on this aspect may appear to be social activism, but without doing so, it will be difficult for the politicians to realize the importance of the same. Although screening for diabetes, diabetes education and promotion of healthy lifestyle has found a place in the public utterences of the Indian health planners, healthy town planning has not yet been appreciated as an important factor in the prevention of non-communicable diseases.

The genetic factors also require a close scrutiny. Although the diabetogenic genes of T2 DM are not clearly identified, it is accepted that the Asian Indians have a higher genetic susceptibility. Even so, it is possible that a section of the population has either non-susceptible genetic composition or a protective genetic composition against the development of T2 DM. An inkling of this fact is seen in the two important prevention studies [21, 22], where life style intervention led to almost same degree $(58 \%)$ of prevention of type $2 \mathrm{DM}$. It can be conceptualized that with the assault of adverse environment factors, a certain percent of genetic population will succumb to diabetes until you reach a residual population which can resist the disease. This fact will tend to blunt the slope of the diabetes curve. With increasing education, it is fervent hope of this author that the prevalence will get blunted. It is also hoped that if India adopts sound method of education, behavioural changes, and town planning, the second epidemic after 2-3 decades will also not visit its population.

\section{References}

1. King H, Herman WH. Global burden of diabetes 1995-2025; prevalence, numerical estimates, and projection. Diabetes Care. 1998;21:1414-31.

2. Wild S, Roglic G, Green A, Sicree R, King H. Global prevalence of diabetes: estimates for the year 2000 and projections for 2030 . Diabetes Care. 2004;27:1047-53.

3. Ramachandran A, Snehalatha C, Latha E, Vijay V, Viswanathan M. Rising prevalence of NIDDM in an urban population in India. Diabetologia. 1997;40:232-7.

4. Ramachandran A, Snehalatha C, Kapur A, Vijay V, Mohan V, Das AK, et al. Diabetes Epidemiology Study Group in India (DESI). High prevalence of diabetes and impaired glucose tolerance in India: National Urban Diabetes Survey. Diabetologia. 2001;44:1094-101.

5. Deo SS, Zantye A, Mokal R, Mithbhawkar S, Rane S, Thakur K. To identify the risk factors for high prevalence of diabetes and impaired glucose tolerance in Indian Rural population. Int J Diab Dev Ctries. 2006;26:19-23.

6. Kokiwar PR, Gupta S, Durge PM. Prevalence of Diabetes in a rural area of central India. Int J Diab Dev Ctries. 2007;27:8-10.

7. Purti AJ, Vedapriya DR, Bazroy J, Gupta S, Cherian J, Viswanathan M. Prevalence of diagnosed diabetes in an urban area of Puducheri, India: Time for preventive action. Int J Diab Dev Ctries. 2009;29:6-11.

8. Gupta SK, Singh Z, Purti AJ, Vishwanathan M. Diabetes prevalence and its risk factors in Urban Pondicherry. Int J Diab Dev Ctries. 2009;29:166-9.

9. Muninarayana C, Balachandra G, Hiremath SG, Iyengar K, Anil NS. Prevalence and awareness regarding diabetes mellitus in rural Tamaka, Kolar. Int J Diab Dev Ctries. 2010;30:18-21. 
10. Rao CR, Kamath VG, Shetty A, Kamath A. A study on the prevalence of type 2 diabetes in Coastal Karnataka. Int J Diab Dev Ctries. 2010;30:80-5.

11. Misra R, Misra A, Kamalamma N, Vikram NK, Gupta S, Sharma $\mathrm{S}$, et al. Difference in prevalence of diabetes, obesity, metabolic syndrome and associated cardiovascular risk factors in a rural area of Tamil Nadu and an urban area of Delhi. Int J Diabetes Dev Ctries 2011;31:

12. King H, Rewers M. Global estimates of diabetes mellitus and impaired glucose tolerance in adults: WHO Ad Hoc Diabetes Reporting Group. Diabetes Care. 1993;16:157-77.

13. Ramachandran A, Snehalatha C, Vijay V. Temporal changes in prevalence of type 2 diabetes and impaired glucose tolerance in urban south India. Diabetes Res Clin Pract. 2002;58:55-60.

14. Mohan V, Deepa M, Deepa R, Shantirani CS, Farooq S, Ganesan A, et al. Secular trends in the prevalence of diabetes and glucose tolerance in urban South India-the Chennai Urban Rural Epidemiology Study (CURES-17). Diabetologia. 2006;49:1175-8.

15. Government of India. Census of India 2001. New Delhi. Revised December 2006. Available from http://www.jsk.gov. in/projection_report_December2006.pdf.
16. Misra A, Vikram NK, Arya S, Pandey RM, Dhingra V, Chattergee A, et al. High prevalence of insulin resistance in postpubertal Asian Indian children isassociated with adverse truncal body fat patterning, abdominal adiposity and excess body fat. Int $\mathrm{J}$ of Obesity. 2004;28:1217-26.

17. Grifftihs P, Bently M. Women of higher socio-economic status are more likely tobe overweight in Karnataka. India Eur J Clin Nutr. 2005;59:1217-20.

18. Pekkanan J, Uutela A, Valkonen T, Vartiainen E, Tuomilehto J, Puska P. Coronary risk factor levels: differences between educational groups in 1972-87 in eastern Finland. J Epidemiol Community Health. 1995;49:144-9.

19. Srinath Reddy K et al. The effect of rural-to-urban migration on obesity and diabetes in India: a cross-sectional study. PLoS med. 2010;7:1-12.

20. Pasala SK, Rao AA, Sridhar GR. Built environment and diabetes. Int J Diab Dev Ctries. 2010;30:63-8.

21. Nathan DM. Initial management of glycemia in type 2 diabetes mellitus. N Engl J Med. 2002;347:1342-9.

22. Tuomilehto J, Lindstrom J, Eriksson J, et al. Prevention of type 2 diabetes mellitus by changes in lifestyle among subjects with impaired glucose tolerance. N Engl J Med. 2001;344:1343-50. 